\title{
PSORIASIS ERUPTIONS-LIKE SIDE EFFECTS AFTER THE USE OF ETANERCEPT - CASE REPORT
}

\author{
Mirjana Veselinovićl, Aleksandra Tomić-Lučićl ${ }^{\text {, Vesna Miličić2 }}$, Ana Ravić Nikolić2 ${ }^{2}$, Ana Aničić3 \\ ${ }^{1}$ University of Kragujevac, Faculty of Medical Sciences, Department of Internal Medicine, Kragujevac, Serbia \\ ${ }^{2}$ University of Kragujevac, Faculty of Medical Sciences, Department of Dermatovenerology, Kragujevac, Serbia \\ ${ }^{3}$ Health Centar "Batocina", Batocina, Serbia
}

\section{PSORIJAZIFORMNA ERUPCIJA KAO NEŽELJENO DEJSTVO ETANERCEPTA - PRIKAZ BOLESNIKA}

\author{
Mirjana Veselinović1, Aleksandra Tomić-Lučić1, Vesna Miličić2 ${ }^{2}$, Ana Ravić Nikolić2 ${ }^{2}$, Ana Aničić3 \\ IUniverzitet u Kragujevcu, Fakultet medicinskih nauka, Katedra za internu medicinu, Kragujevac \\ ${ }^{2}$ Univerzitet u Kragujevcu, Fakultet medicinskih nauka, Katedra za dermatovenerologiju, Kragujevac \\ ${ }^{3}$ Dom zdravlja ,Batočina“, Batočina
}

\begin{abstract}
The use of tumor necrosis factor antagonists (anti-TNF) has become a usual practice to treat various inflammatory diseases. Although indicated for the treatment of psoriasis, anti-TNF may paradoxically trigger a psoriasiform condition. We present a case of a female patient who, during the use of etanercept for rheumatoid arthritis, developed psoriasis. After histopathological confirmation and consultation, the dermatologist concluded that psoriasis was a paradoxical effect of anti-TNF inhibitors. Anti-TNF inhibitor is replaced with other biological drug- tocilizumab. After the change of the drug, psoriasis eruptions were completely resolved. The paradoxical form of psoriasis after the use of anti-TNF inhibitor requires a change of the drug with other mechanism of action.
\end{abstract}

Keywords: psoriasis; arthritis, rheumatoid; tumor necrosis factor-alpha; etanercept; drug-related side effects and adverse reactions.

\section{INTRODUCTION}

Psoriasis is a chronic immune-mediated inflammatory skin disease with a genetic component and a wide range of clinical manifestations. It affects around $1 \%-2 \%$ of the world's population (1). The use of biopharmaceuticalsespecially tumor necrosis factor antagonists (anti-TNFs)has become a common practice in the treatment of various inflammatory diseases such as rheumatoid arthritis, psoriasis, inflammatory bowel diseases, spondylitis ankylopoetica. Side effects of this therapy include new forms or change in the pattern of the psoriasis lesions or even worsening of symptoms, in patients with or without prior psoriasis or psoriatic arthritis. This phenomenon is called paradoxical psoriasis. It occurs in approximately $5 \%$ of patients using anti-TNF drugs. Although the disorder affects both sexes, it has as light predilection for women (1-4). The time between the introduction of the medication and the appearance of lesions can range from a few days to many months.

\section{SAŽETAK}

Inhibitori faktora nekroze tumora (TNF) koriste se $u$ terapiji inflamatornih oboljenja. Jedna od neželjenih reakcija ovih lekova jeste pojava psorijaziformne erupcije koja se označava kao paradoksalna psorijaza.U ovom radu predstavili smo pacijentkinju sa reumatoidnim artritisom, kod koje se razvila psorijaza u toku primene entanercepta. Nakon patohistološke potvrde i konsultacije dermatologa zaključeno je da je psorijaza paradoksalni efekat anti-TNF inhibitora. Anti-TNF inhibitor je zamenjen drugim biološkim lekom-tocilizumabom. Nakon promene leka došlo je do potpune rezolucije promena po koži. Paradoksalna forma psorijaze nakon upotrebe anti-TNF inhibitora zahteva promenu leka s drugim mehanizmom dejstva.

Ključne reči: psorijaza; artritis, reumatoidni; faktor nekroze tumora-alfa; etanercept; neželjena dejstva u vezi s lekovima i neželjene reakcije.

The most commonly reported clinical forms are palmoplantar pustular psoriasis followed by plaque-type psoriasis and guttate psoriasis (5). Nail and scalp involvement have also been described. Some patients may experience more than one type of lesions. The treatment of the paradoxical phenomenon of psoriasis is still a challenge because most patients need anti-TNF inhibitors to control the underlying disease. We report a female patient using anti-TNF inhibitors for rheumatoid arthritis, who developed paradoxical psoriasis.

\section{CASE REPORT}

We report a 47-year-old white female patient, married, born and raised in Kragujevac, diagnosed with rheumatoid arthritis since 2007. She was treated with prednisone (10 $\mathrm{mg}$ /daily) and methotrexate (20 mg/weekly) without a satisfactory response. During 2015 thisled to clinical exacerbations and increases of the dose of metotrexato $25 \mathrm{mg}$ a week and adding Sulfasalazine $2 \mathrm{~g}$ per day. After one year, because of the high activity of the disease, anti- 


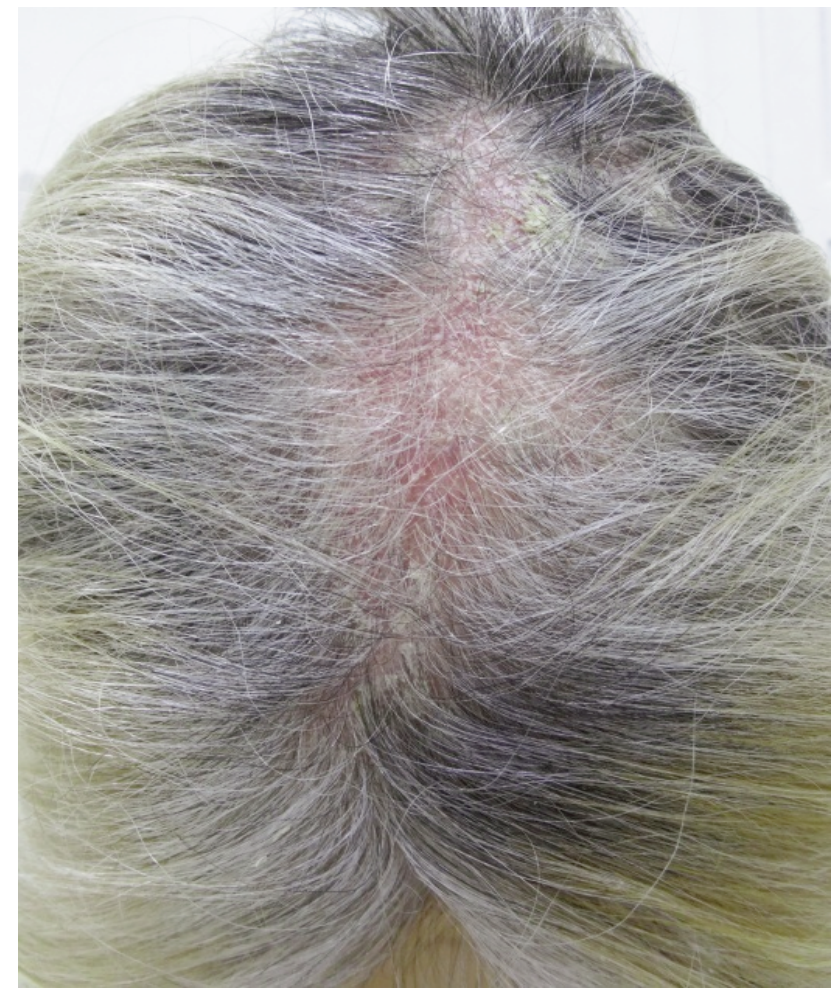

Figure 1. Skin lesions after treatment with etenercept.

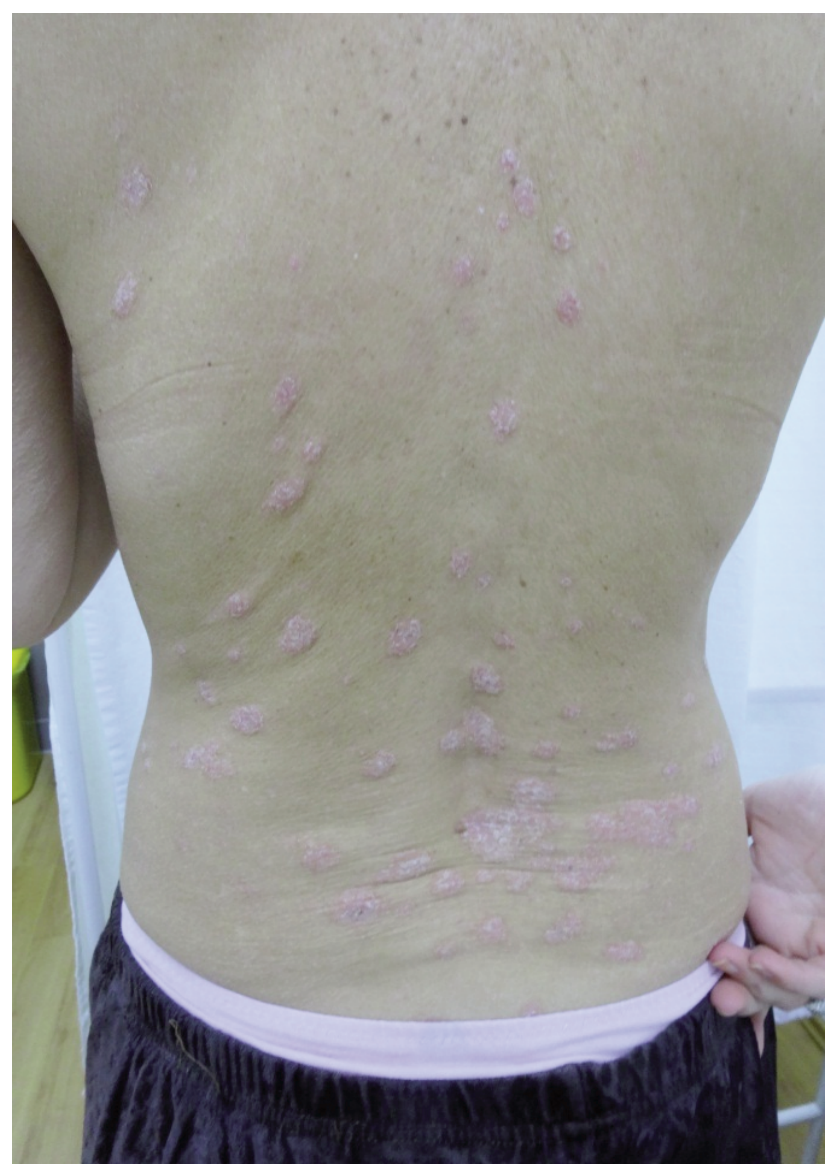

Figure 2. Skin lesions after treatment with etanercept.
TNF inhibitor- etanercept 50mg per week was added to the therapy subcutaneously. She started using etanerceptand 10 months later, she was presented with disseminated erythematous plaques with white patches, smaller nonadherent scaly plaques on the skin of the trunk and extremities, predominantly lumbosacral. In frontoparietal scalp erythematous plaques were presented, covered with distinctive white patches with thinning hair (Figures 1 and 2). Laboratory results: SE 30/, RF 320, anti CCP At 280, ANA negative, virological analysis-negative, the other values in the normal range.

Histopathological examination results of one of the lesions were consistent with psoriasis: moderate psoriasiform epidermal hyperplasia, absent stratum granulosum, and parakeratotic stratum corneum permeated by neutrophils associated with perivascular and superficial inflammatory infiltrate consisting of lymphocytes, neutrophils and eosinophils (Figure 3). We switched from etanercept to tocilizumab $8 \mathrm{mg} / \mathrm{kg}$ every 4 weeks. After the first dose, four weeks later, we observed a complete resolution of the lesions. The patient was treated in dermatology daycare center multiple days a week with different topical therapies and UVB photo-therapy. Rheumatoid arthritis after a month of treatment with tocilizumab had low disease activity (DAS 28 CRP-3,1).

\section{DISCUSSION}

Anti-TNF- $\alpha$ therapies are widely used in the treatment of inflammatory disorders, such as psoriasis, arthritis, ankylosing spondylitis and inflammatory bowel diseases. Side effects of these treatments have been reported, including a de novo or worsening of psoriatic eruption. This adverse reaction is also known in the literature as paradoxical psoriasis. Many case reports and case series have been published to describe these patients who used either infliximab, adalimumab or etanercept, with an incidence of $1-5 \%$ (6-9). The etiology of this manifestation is not well-defined but seems to be related

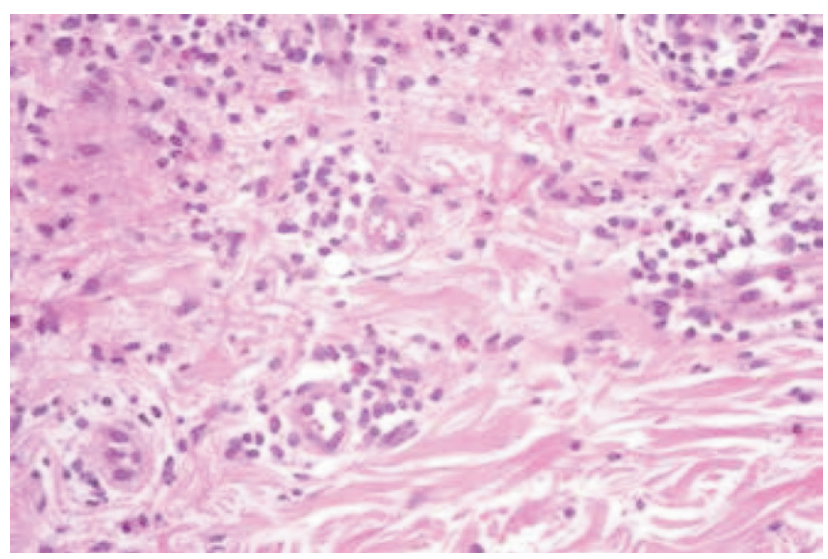

Figure 3. Skin biopsy shows hyper-and parakeratosis, subcorneal pustules with neutrophilic granulocytes and spongiosis, a perivascular inflammation with extravasation of neutrophilic granulocyte. 
to the balance between the levels of tumor necrosis factor alpha (TNF-alpha) and interferon (IFN), with increased levels of the latter cytokine $(5,10)$. Gannes et al. suggested that inhibition of TNF-alpha may stimulate uncontrolled production of interferon-alpha (IFN-alpha), which in certain patients can induce the development of the disease. The authors also showed that the expression and activity of IFN-alpha were increased in patients who developed psoriasis during a treatment with anti-TNF drugs compared to patients with previous psoriasis vulgaris (11).

The treatment of psoriasis induced by anti-TNF drugs depends on the severity of the clinical picture and still represents a therapeutic challenge. In milder cases, topical treatment and phototherapy can be prescribed in an attempt to control the skin condition efficiency to immunobiological agent, which is often the only effective drug for the treatment of the underlying disease. The suspension of the implicated biologic agent is associated with a higher resolution rate, but often the suspension alone is not enough. The suspension of the anti-TNF drug associated with the start of systemic medication for psoriasis resulted in higher cure rates: approximately $64 \%$ versus $44 \%$ when systemic medications started without suspension of the immunobiological agent $(5,12,13)$. Thus, another type of anti-TNF agent can be used for the treatment of the underlying disease. One study showed an improvement of the skin condition in $15 \%$ of cases when anti-TNF medications were switched (5).

However, paradoxical psoriasis may be persistent or even get worse. In most cases, no improvement in skin condition is reported, suggesting a class effect, and not the effects of a specific medication (5). In this context, treatment of the underlying disease becomes a challenge, since the anti-TNF drug is often the effective treatment for the underlying disease. In the present case report, the presence of eosinophils in histopathology suggested medication as a trigger, which explains our option to switch anti-TNF agents to biological drug with a different mechanism of action-tocilizumab (monoclonal antibodies against IL6) (14). In the reported case, the patient was able to achieve adequate control of rheumatoid arthritis with new immunobiological drug. In this case report, we present a patient with a rheumatoid arthritis, who developed a psoriatiform eruption after the treatment with etanercept. Different topical psoriasis treatments showed a partial response the psoriatic lesions. Switching to tocilizumab, anti-IL6 treatment, resulted in a complete remission of the skin lesions and good control of her rheumatoid arthritis.

\section{REFERENCES}

1. Sociedade Brasileira de Dermatologia. ConsensoBrasileiro de Psoríase 2012: guias de avaliação e tratamento. 2nd. ed. Rio de Janeiro: Sociedade Brasileira de Dermatologia, 2012. (in Portuguese).
2. Joyau C, Veyrac G, Dixneuf V, Jolliet P. Anti-tumour factor alpha therapy and increased risk of de novo psoriasis: is it really a paradoxical side effect? Clin Exp Rheumatol 2012; 30: 700-6.

3. Puig L, Morales-Múnera CE, López-Ferrer A, Geli C. Ustekinumab treatment of TNF antagonist-induced paradoxical psoriasis flare in a patient with psoriaticarthritis: case report and review. Dermatology 2012; 225: 14-7.

4. Denadai R, Teixeira FV, Steinwurz F, Romiti R, SaadHossne R. Induction or exacerbation of psoriatic lesions during anti-TNFa therapy for inflamatory bowel disease: A systemic literature review based on 222 cases. J Crohns Colitis 2013; 7: 517-24.

5. Wollina U, Hansel G, Koch A, Schönlebe J, Köstler E, Haroske G. Tumor necrosis factor- $\alpha$ inhibitor-induced psoriasis or psoriasiform exanthema. First 120 cases from the literature including a series of six new patients. Am J Clin Dermatol 2008; 9: 1-14.

6. Nguyen K, Vleugels RA, Velez NF, Merola JF, Qureshi AA. Psoriasiform reactions to anti-tumor necrosis factor $\alpha$ therapy. J Clin Rheumatol 2013; 19: 377-81.

7. Collamer AN, Battafarano DF. Psoriatic skin lesions induced by tumor necrosis factor antagonist therapy: clinical features and possible immunopathogenesis. Semin Arthritis Rheum 2010; 40: 233-40.

8. Shmidt E, Wetter DA, Ferguson SB, Pittelkow MR. Psoriasis and palmoplantar pustulosis associated with tumor necrosis factor- $\alpha$ inhibitors: the Mayo Clinic experience, 1998 to 2010. J Am Acad Dermatol 2011; 67: 179-85.

9. Ko JM, Gottlieb AB, Kerbleski JF. Induction and exarcerbation of psoriasis with TNF-blockade therapy: A review and analysis of 127 cases. J Dermatolog Treat 2009; 20: 100-8.

10. Brunasso AM, Laimer M, Massone C. Paradoxical reactions to targeted biological treatments: a way to treat and trigger? Acta DermVenereol 2010; 90:183-5.

11. Fernandes IC, Torres T, Sanches M, Velho G, Lago P, Selores M. Psoriaseinduzida por infliximab. Acta Med Port 2011; 24: 709-13. (in Portuguese).

12. Denadai R1, Teixeira FV, Saad-Hossne R. The onset of psoriasis during the treatment of inflammatory bowel diseases whit infliximab: should biological therapy be suspended? Arq Gastroenterol 2012; 49: 172-6.

13. Navarro R, Daudén E. Clinical management of paradoxical psoriasiform reactions during TNF- $\alpha$ therapy. ActasDermosifiliogr 2014; 105: 752-61.

14. Laga AC, Vleugels RA, Qureshi AA, Velazquez EF. Histopathologic spectrum of psoriasiform skin reactions associated with tumor necrosis factor-a inhibitor therapy. A Study of 16 Biopsies. Am J Dermatopathol 2010; 32: 568-73. 